\title{
ANALISIS FAKTOR - FAKTOR YANG MENDORONG TINDAKAN TAX EVASION PADA WAJIB PAJAK UMKM DI KECAMATAN MADIDIR KOTA BITUNG
}

\author{
Arif A. Palowa ${ }^{1}$, Grace B. Nangoi ${ }^{2}$, Natalia Y.T. Gerungai ${ }^{3}$ \\ 1,2,3 Jurusan Akuntansi, Fakultas Ekonomi dan Bisnis, Universitas Sam Ratulangi, Jl. Kampus Bahu, Manado, \\ 95115, Indonesia
}

E-Mail : palowa.arif@gmail.com

\begin{abstract}
The needs of local governments to the central government in the framework of financing and the level of community compliance to pay taxes in accordance with what is owed is the focus that needs to be discussed. For this reason, this study aims to analyze the factors that encourage tax evasion according to individual taxpayers in Madidir District, Bitung City. This type of research is qualitative descriptive, and the data used is primary data. Data obtained through direct interviews with seven informants in the city of Bitung based on the results of research on the analysis of factors - factors that encourage tax evasion in the form of reducing, removing, and illegal manipulation of tax burden according to taxpayers in Madidir Subdistrict, Bitung City can be concluded that the driving factor society takes action tax evasion is a fare factor that makes the tax burden to be high, economic factors, taxes system factor that too complicated, compliance factors that aim to enrich themselves, the government firmness factor, and distrust of the government bureaucracy.
\end{abstract}

Keywords: tax, factors, tax evasion.

\section{PENDAHULUAN}

Indonesia merupakan negara berkembang yang masih membutuhkan dukungan dari masyarakat untuk menjadi negara maju. Bukan hanya sekedar dukungan ide melainkan masyarakat perlu menjadi sumber penerimaan negara melalui pembayaran pajak. Hal itu dikarenakan pajak merupakan sumber utama penerimaan negara yang digunakan untuk membiayai pengeluaran negara untuk memenuhi kebutuhan masyarakat dan melaksanakan pembangunan. Kedua hal tersebut tentunya membutuhkan dana yang tidak sedikit. Menurut Prof Dr. P.J.A Adriani, pengertian pajak ialah iuran yang dibayarkan kepada negara (yang dapat dipaksakan) yang terutang oleh yang wajib membayar berdasarkan peraturan-peraturan dengan tidak mendapat balasan kembali, yang langsung dapat ditunjuk dan digunakan untuk membiayai pengeluaran umum yang berkaitan dengan tugas negara untuk menyelenggarakan pemerintahan. Bayangkan saja jika pajak tidak mampu menjadi aktor utama penerimaan negara disaat ekspektasi terhadap penerimaan negara dari Pajak sangat tinggi, tentunya seluruh cita-cita yang di dambakan semua orang di negara ini akan pupus dan menyebabkan tertinggalnya pembangunan diseluruh pelosok negeri. Maka dari itu, semua masyarakat yang menurut undang-undang merupakan wajib pajak, wajib membayar pajak sesuai kewajibannya.

Pertumbuhan nasional sendiri telah mengalami perubahan drastis pada era Presiden Joko Widodo. Akan tetapi pendanaan asing masih menjadi batu pijakan dominan dalam hal pembangunan. Hal itu dapat mengindikasikan bahwa pajak yang selama ini diproyeksikan menjadi pilar utama penerimaan negara belum menjadi tokoh utama dalam pembangunan negara secara mandiri. Apabila seluruh masyarakat taat membayar pajak maka akan menciptakan bangsa yang mampu berdiri di kaki sendiri dimana dengan pajak ini, percepatan 
pembangunan tidak perlu menggantungkan diri terhadap pinjaman luar negeri. Secara umum perekonomian dalam negeri masih belum membaik, masih ada beberapa daerah mengalami ketertinggalan dalam pembangunan meskipun pemerintah telah mengupayakan pembangunan dari pelosok negeri. Begitu juga dengan adanya pergolakan politik yang mempengaruhi perekonomian dalam negeri, ketidakmampuan sumber daya dalam negeri dalam dunia kerja, hingga tindak pidana korupsi yang membuat masyarakat seakan hilang kepercayaan kepada pemerintah dalam membayar pajak. Segala upaya telah pemerintah lakukan akhir-akhir ini melalui Direktorat Jenderal Pajak yang mengagendakan perluasan subyek dan obyek pajak atau dengan menjaring wajib pajak baru terutama para pelaku Usaha Mikor Kecil Menengah (UMKM). Dengan diterbitkannya Peraturan Pemerintah Nomor 23 Tahun 2018, memperluas subjek pajak yang perlu membayarkan pajaknya. Beberapa pengecualian dihapuskan seperti wira usaha yang selesai berjualan membongkar tempat usahanya sudah tidak dikecualikan dalam membayar pajak. Para pedagang di pasar tradisional selaku UMKM menjadi subjek perluasan dari neraturan tersebut. Dalam usaha lain pemerintah untuk meningkatkan penerimaan pajak, antara lain dengan peningkatan kualitas aparatur perpajakan, peningkatan pelayanan, penyederhanaan aturan dan tatacara pembayaran pajak, hingga peningkatan pengetahuan perpajakan wajib pajak. Peningkatan pemegang NPWP tidak berbanding lurus denganp penerimaan negara. Oleh karena itu dapat disimpulkan bahwa kenaikan realisasi Pajak tidak serta-merta dapat dikatakan hal positif jika segala bentuk penggelapan pajak masih terjadi di negeri ini.

Dengan bergantinya pemerintahan daerah di Indonesia memasuki Tahapan baru dengan dimplementasikan Undang-Undang No. 23 Tahun 2014 tentang Pemerintahan daerah yang merupakan pengganti dari Undang-Undang terdahulu yaitu Undang-Undang No. 32 Tahun 2004 yang dinilai tidak lagi sesuai dengan zaman, perkembangan keadaan, ketatanegaraan dan tuntutan penyelenggaraan pemerintah saerah. Dalam rangka mendorong kelancaraan pelaksanaan otonomi daerah, pemerintah pusat telah mengeluarkan UndangUndang Nomor 33 Tahun 2004 tentang Perimbangan Keuangan Antara Pemerintah Pusat dan Daerah, sehingga kekuatan dari desentralisasi fiskal yang direncanakan tersebut diharakan akan mampu memberikan kebebasan kepada daerah untuk mengurus dan mengatur rumah tangganya sendiri. Pemerintah Kota Bitung layaknya sebagian besar kota lain di Indonesia yang saat ini dalam penyelenggaraan pemerintahan tidak terlepas dari subsidi pemerintah pusat dalam bentuk Dana Alokasi Umum (DAU) seperti yang dapat dilihat pada Tabel 1.

Tabel 1. Kontribusi Dana Alokasi Umum Kota Bitung Tahun Anggaran 2015-2017

\begin{tabular}{ccr}
\hline Tahun Anggaran & Dana Alokasi Umum & \% Kenaikan DAU \\
\hline 2015 & $437.048 .958 .000,00$ & - \\
2016 & $482.867 .542 .000,00$ & $12.1 \%$ \\
2017 & $500.354 .000 .000,00$ & $3.7 \%$ \\
\hline
\end{tabular}

(Sumber : Dinas Pendapatan Kota Bitung)

Dari Tabel 1 dapat dilihat bahwa perkembangan DAU selama periode tiga tahun terakhir dengan kenaikan 7.9\%. Data di atas menunjukan bahwa Kota Bitung masih memiliki ketergantungan yang tinggi terhadap bantuan pemerintah pusat. Dukungan pajak sangat dibutuhkan untung pendanaan strategis. Pajak erat kaitannya dengan pembangunan daerah. Akan tetapi hambatan dalam pajak merupakan hal yang seperti tidak ada habisnya. Karena masyarakat banyak masyarakat belum menyadari arti penting pajak sebagai pilar utama pembangunan. Tax planning (perencanaan pajak) merupakan salah satu langkah yang ditempuh oleh para wajib pajak. Wajib pajak berusaha mengurangi pajak yang terutang dengan berbagai cara. Tax avoidance dan tax evasion merupakan langkah yang di ambil oleh wajib pajak. Meskipun keduanya mempunyai tujuan untuk mengurangi beban pajak, akan 
tetapi karakteristik dari keduanya sangat berbeda. Tax Avoidance merupakan tindakan penghindaran pajak dengan memanfaatkan celah-celah (loophole) peraturan-peraturan dan perundang-undangan perpajakan. Tax avoidance sendiri merupakan tindakan legal di Indonesia. Akan tetapi sulitnya melakukan tax avoidance masyarakat cenderung melakukan tindakan tax evasion untuk mengurangi beban pajak. Tentunya tindakan Tax Evasion adalah sesuatu yang bertujuan untuk mengurangi beban pajak dengan cara melanggar peraturanperaturan dan perundang-undangan perpajakan di Indonesia.

\section{TINJAUAN PUSTAKA}

Akuntansi merupakan suatu proses pengidentifikasian, pengukuran, pencatatan, pelaporan atas transaksi keuangan suatu organisasi/entitas yang digunakan untuk informasi pengambilan keputusan ekonomi untuk pihak internal mapun eksternal (Halim dan Kusufi. $2014: 3)$.

Akuntansi pajak. Menurut Agoes dan Estralita (2013 : 10) ialah sebagai berikut : "Akuntansi pajak adalah menetapkan besarnya pajak terutang berdasarkan laporan keuangan yang disusun telah oleh perusahaan".

Pajak. Menurut Prof Dr. Rochmat Soemitro, S.H. (1994) yang dikutip dalam Mardiasmo (2018 : 1), pajak merupakan iuran rakyat yang dibayarkan kepada kas negara berdasarkan undang-undang (dapat dipaksakan) dengan tidak mendapat jasa timbal (kontrapretasi) yang langsung dapat ditunjukkan dan yang digunakan untuk membayar pengeluaran umum.

Fungsi Pajak. Ada dua fungsi pajak, yaitu: (1) fungsi anggaran (budgetair); dan (2) fungsi mengatur (cregulerend).

Wajib Pajak UMKM. Wajib pajak UMKM menurut UU No. 20. Tahun 2008 tentang UMKM yaitu usaha mikro, kecil, dan menengah produktif milik perorangan dan atau badan yang memenuhi syarat berdasarkan undang-undang ini. WP UMKM dikenakan pajak penghasilan final $0.5 \%$ dalam jangka waktu tertentu.

Tax Evasion. Menurut Rahayu (2010 : 147), Tax Evasion yaitu Pengelakan Pajak (tax evasion) adalah usaha aktif wajib pajak dalam hal mengurangi, menghapuskan, manipulasi ilegal terhadap utang pajak atau meloloskan diri dan tidak membayar pajak sebagaimana yang telah terutang menurut aturan perundang-undangan.

\section{METODOLOGI PENELITIAN}

Jenis Penelitian. Ditinjau dari jenis datanya pendekatan penelitian yang digunakan dalam penelitian ini adalah pendekatan kualitatif. Menurut Moleong (2011:6), penelitian kualitatif merupakan penelitian yang bertujuan memahami fenomena tentang apa yang dirasakan oleh subjek penelitian misalnya, perilaku, persepsi, tindakan dan lain-lain secara menyeluruh dan dengan penjabaran deskripsi berbentuk kata-kata dan bahasa, pada suatu konteks khusus yang dialami dan dengan memanfaatkan berbagai metode penelitian.

Tempat dan Waktu Penelitian. Tempat penelitian ini yaitu Kecamatan Madidir Kota Bitung Provinsi Sulawesi Utara. Waktu penelitian yang dibutuhkan sekitar 3 bulan.

\section{Metode Pengumpulan Data}

Jenis Data. Data yang dipakai dalam penelitian ini ialah kualitatif. Data kualitatif dalam penelitian ini yaitu jawaban masyarakat Kecamatan Madidir Kota Bitung tentang tindakan tax evasion.

Sumber Data. Data Primer meruapakan data yang mengacu pada informasi yang diperoleh peneliti itu sendiri yang berhubungan dengan variabel minat untuk keperluan penelitian. Sumber data primer adalah informan individu, kelompok fokus, internet juga dapat menjadi sumber data primer jika kuisioner disebarkan melalui internet (Uma Sekaran, 2011). Pada 
penelitian ini, peneliti memfokuskan diri pada wajib pajak dengan kriteria: (1) yang telah memiliki penghasilan melalui kegiatan usaha dan telah memenuhi syarat untuk dikenakan pajak; dan (2) mengetahui tentang tindakan tax evasion.

Teknik Pengumpulan Data. Teknik pengumpulan data dalam penelitian ini sebagai berikut :

1. Dokumentasi. Dokumentasi digunakan untuk mengumpulkan data kemudian ditelaah. Data yang di dokumentasikan dalam penelitian ini yaitu gambaran umum Kota Bitung.

2. Wawancara. Pertanyaan dalam penelitian ini mengacu pada definisi tax evasion yaitu tindakan mengurangi, menghapuskan, dan manipulasi ilegal beban pajak untuk mencari tahu mengenai faktor-faktor yang mendorong tindakan tersebut.

3. Observasi. Peneliti mengamati segala gejala ataupun fenomena yang terjadi pada objek penelitian dengan tujuan untuk mencocokan keadaan objek penelitian dengan pengakuan dari para informan.

Metode Analisis. Dalam penelitian ini akan menganalisa :

1. Faktor - faktor yang mendorong tindakan tax evasion dalam bentuk mengurangi beban pajak.

2. Faktor - faktor yang mendorong tindakan tax evasion dalam bentuk menghapuskan beban pajak.

3. Faktor - faktor yang mendorong tindakan tax evasion dalam bentuk manipulasi ilegal beban pajak.

Proses Analisis. Dalam penelitian ini peneliti akan melakukan serangkaian proses analisis data. Proses analisis data di dalam penelitian ini sebagai berikut :

1. Tahap pertama. Peneliti mengumpulkan dan menganalisa data-data yang diperlukan dalam penelitian ini. Data diperoleh lewat wawancara langsung dan dokumentasi kepada Informan wajib pajak UMKM di Kecamatan Madidir Kota Bitung. Data-data tersebut berupa pengakuan, pandangan mengenai faktor-faktor yang mendorong tindakan tax evasion, serta saran informan yang kiranya mampu mengatasi tindakan tax evasion.

2. Tahap kedua. Hasil dari analisa tersebut akan dibahas dan selanjutnya akan diperbandingkan dengan peraturan perpajakan yang berlaku, teori yang mendukung tentang pentingnya membayar pajak serta penelitian terdahulu. Tujuan dilakukan langkah ini adalah untuk mengetahui pandangan masyarakat mengenai peraturan pajak apakah masih dirasa berat atau tidak serta mengetahui sikap pribadi wajib pajak UMKM tentang faktor yang melatarbelakangi wajib pajak UMKM dalam melakukan tindakan tax evasion.

3. Tahap ketiga. Peneliti memberikan kesimpulan atas hasil pembahasan dan perbandingan yang telah dilakukan tahap sebelumnya.

4. Tahap keempat. Apabila hasil analisa mengenai faktor-faktor yang mendorong tindakan tax evasion pada wajib pajak di Kecamatan Madidir Kota Bitung telah dihimpun dengan baik dan didapati faktor-faktor itu, maka peneliti akan memberikan saran melalui analisa peneliti sendiri serta saran yang diberikan para Informan dalam penelitian ini untuk mengatasi tindakan tax evasion pada wajib pajak di Kecamatan Madidir Kota Bitung. Tujuan dilakukannya langkah ini adalah untuk membantu pemerintah dalam mengevaluasi sistem dan aturan perpajakan terkait kecenderungan wajib pajak dalam penghindaran pajak.

\section{HASIL PENELITIAN DAN PEMBAHASAN}

\subsection{Hasil Penelitian}

Faktor Yang Mendorong Tindakan Mengurangi Beban Pajak. Berdasarkan wawancara yang dilakukan pada Bapak Thomas F. yang memiliki usaha ternak ayam, memberikan pengakuan bahwa tindakan tax evasion dalam bentuk mengurangi beban pajak 
yang dilakukan wajib pajak UMKM adalah karena beban pajak yang terlalu tinggi. Seperti yang terjadi pada usaha Informan ini, bahwa usaha yang dibangun informan menggunakan pinjaman bank yang dimana setiap periodenya mendapatkan untung yang sedikit bahkan hampir merugi. Bapak Thomas juga mengatakan tindakan tax evasion terjadi karena tidak diketahui oleh pemerintah. Hal yang sama dikatakan oleh Informan Bapak Riangto B. yang memiliki usaha jual - beli handphone, pulsa, dan aksesoris handphone, bahwa tindakan tax evasion dalam bentuk mengurangi beban pajak muncul karena faktor beban tarif yang dirasa terlalu tinggi. Maka dari itu Informan ini tidak melaporkan pendapatannya. Penjualan yang tidak mencapai target adalah hal yang dirasa berat oleh Bapak Riangto B.. Informan lainnya yang memiliki usaha Rumah Makan, Pak Roni, lewat wawancara langsung memberikan pendapat bahwa tindakan tax evasion dalam bentuk mengurangi beban pajak disebabkan karena faktor ekonomi. Seperti yang terjadi pada usaha Informan bahwa perlu ada penyisihan pendapatan untuk membayar gaji pegawai.

Faktor Yang Mendorong Tindakan Menghapuskan Beban Pajak. Menurut Bapak Maxi selaku pemilik Rumah Makan, tindakan Tax Evasion dalam bentuk menghapuskan beban pajak didasari atas kepentingan pribadi dan dianggap ilegal oleh Bapak Maxi. Bapak Sucipto selaku pedagang memberikan pendapat yang sama, bahwa tindakan tax evasion dalam bentuk menghapuskan beban pajak didasari atas dorongan untuk memperkaya diri sendiri dan faktor dorongan untuk memenuhi kebutuhan. Bapak Riangto B. (konter hp dan aksesoris), dan Bapak Roni (pemilik rumah makan) juga berpendapat ada unsur dorongan ekonomi yang mendasari seseorang melakukan tindakan tax evasion dalam bentuk menghapuskan beban pajak. Bapak Deni (pemilik toko printer) dan Bapak Maxi (supir taksi dan pemilik kantin) berpendapat bahwa tindakan tax evasion dalam bentuk menghapuskan beban pajak didasari atas ketidakpercayaan kepada birokrasi pemerintah. Menurut Bapak Maxi pejabat kaya dengan mudahnya menghapuskan beban pajak, apalagi mereka yang merupakan masyarakat menengah kebawah. Informan ini berpendapat bahwa tindakan tax evasion terjadi karena adanya unsur ketidakpercayaan kepada pemerintah yang melakukan praktek korupsi. Informan ini merasa bahwa mencari uang untuk membayar pajak disaat korupsi merajalela adalah sia-sia. Maka dari itu berimbas pada keengganan Informan ini untuk ikut andil dalam mengikuti kewajiban perpajakan. Sedangkan Bapak Deni (Pemilik Toko Printer) berpendapat bahwa ketidakpercayaan kepada pemerintah karena kurang meratanya pembangunan. Lewat wawancara langsung dengan pemilik usaha ternak ayam bapak Thomas F. tindakan tax evasion dalam bentuk menghapuskan beban pajak karena faktor keuntungan yang tidak seberapa. Seperti yang terjadi pada usaha Bapak Thomas F. yang hampir merugi pada usahanya. Mayoritas informan lain mengatakan bahwa tindakan tax evasion dalam bentuk menghapuskan beban pajak didasari oleh faktor ekonomi dan kepentingan pribadi untuk memperkaya diri sendiri.

Faktor Yang Mendorong Tindakan Manipulasi Ilegal Beban Pajak. Lewat wawancara langsung dengan Bapak Roni (pemilik rumah makan), tindakan tax evasion dalam bentuk manipulasi ilegal beban pajak terjadi karena keperluan bukti karena banyak kehilangan faktur yang nantinya akan mempengaruhi belanja dan pendapatan mereka. dalam rangka menutup ketidakadaan faktur, informan ini membuat faktur/nota palsu. Pendapat lainnya datang dari 4 (empat) informan lain yang menanggapi tentang faktor seseorang melakukan Praktik Manipulasi ilegal beban pajak yaitu perilaku tidak jujur dari orang tersebut dan adanya ketidaknyamanan dengan tarif yang ada. 1 (satu) informan lain mengatakan adanya faktor ekonomi yang menjadi pendorong, 1 (satu) informan lainnya berpendapat yang menjadi faktor seorang wajib pajak melakukan tindakan tax evasion dalam bentuk manipulasi ilegal adalah rasa tidak percaya kepada birokrasi pemerintah. 


\subsection{Pembahasan}

Faktor Yang Mendorong Tindakan Mengurangi Beban Pajaknya. Bentuk mengurangi beban pajak secara ilegal adalah melaporkan penjualan lebih kecil dari yang seharusnya dan menggelembungkan biaya perusahaan dengan membebankan biaya fiktif (Prihadi, 2009). Mengurangi beban pajak dapat dilakukan dengan benar apabila mentaati peraturan yang ada. Suatu perusahaan dapat melakukan perencanaan pajak demi mengurangi beban pajak yang dirasa terlalu tinggi. Perencanaan pajak bertujuan merekayasa agar beban pajak (tax burden) dapat ditekan serendah mungkin dengan menggunakan peraturan yang ada untuk memaksimalkan penghasilan setelah pajak (after tax return), karena pajak merupakan unsur pengurang laba yang tersedia, baik untuk dibagikan kepada pemegang saham maupun untuk diinvestasikan kembali (Suandy, 2011 : 7). Dengan memanfaatkan loopholes pada peraturan perundang-undangan, wajib pajak dapat melakukan tindakan tax avoidance yang legal. Akan tetapi tak jarang wajib pajak salah jalan dan melakukan tindakan ilegal yang disebut tax evasion. Berkaitan dengan penelitian ini, terdapat 8 (delapan) informan di Kecamatan madidir Bitung Kota Bitung yang dimana ada yang mengemukakan lebih dari 1 (satu) faktor yang mendorong wajib pajak untuk melakukan tindakan tax evasion dalam bentuk mengurangi beban pajak. 3 (tiga) informan berpendapat bahwa tindakan itu didasari oleh faktor beban pajak yang tinggi, 4 (empat) informan mengatakan faktor ekonomi yang mendasari, 2 (dua) informan mengatakan sistem perpajakan yang rumit, 1 (satu) informan mengatakan adanya faktor ketidaktegasan pemerintah, 1 (satu) informan mengatakan faktor ketidakpercayaan kepada birokrasi pemerintah mendorong seseorang untuk melakukan tindakan tax evasion dalam bentuk mengurangi beban pajak. Apabila kita meninjau aturan yang ada yaitu Peraturan Menteri Keuangan Nomor 182/PMK.03/2015 Pasal 2 ayat 1 dan 2, pengusaha yang telah memenuhi persyaratan subjektif dan objektif wajib melaporkan penghasilan dan membayar sesuai pajak yang terutang tanpa mengurangi beban pajaknya. Wajib lapor perlu dilakukan oleh wajib pajak yang berkegiatan usaha dan memiliki penghasilan atas usaha yang ia jalani meskipun keuntungan kecil. Adapun tarif yang ditetapkan oleh pemerintah kepada wajib pajak UMKM yang dimaksudkan dalam penelitian ini :

1. $0.5 \%$ dari peredaran bruto bagi wajib pajak UMKM dengan peredaran bruto kurang dari Rp. 4.800.000.000.

2. Tarif pajak progresif pasal 17 bagi wajib pajak UMKM yang mendapatkan gaji, upah honorarium, dan sebagainya.

3. Pajak Restoran $10 \%$ dari harga makanan bagi pengusaha Restoran.

Dari penelitian ini dapat dilihat bahwa tarif pajak dibawah $1 \%$ ataupun segala bentuk fasilitas pengurang kewajiban pajak tidak dapat menjamin masyarakat mau melaporkan beban pajaknya tanpa mengurangi beban pajak secara legal. Meningkatkan kepatuhan wajib pajak untuk tidak mengurangi beban pajaknya adalah suatu hal yang sulit, mengapa demikian? Melaksanakan pemeriksaan kepada suatu usaha memerlukan waktu dan transparansi dari orang yang bersedia untuk diperiksa. Wajib pajak yang melakukan tindakan tax evasion dalam bentuk mengurangi cenderung akan menyembunyikan bukti-bukti yang ada. Akan tetapi mengurangi beban pajak semata-semata bukan untuk mencurangi aturan yang ada, namun beban pajak yang dirasa terlalu tinggi ataupun keperluan ekonomi yang mendadak membuat wajib pajak UMKM harus berputar otak. Apabila ada kebutuhan, maka hal itu akan mendorong organisme untuk berperilaku atau bertindak untuk memperoleh kebutuhan yang diperlukan untuk melangsungkan eksistensinya sebagai makhluk hidup, seperti mendapat keuntungan yang lebih besar, kebutuhan hidup enak, tuntutan dari kebutuhan keluarga, dan lain sebagainya. (Binarni, 2016) Seperti pada Informan Bapak Thomas F. yang dengan terpaksa mengurangi bahkan tidak melaporkan karena keuntungannya tidak seberapa. 
Faktor Yang Mendorong Tindakan Menghapuskan Beban Pajaknya. Zain (2008 : 49) berpendapat bahwa tax evasion adalah usaha yang dilakukan oleh wajib pajak untuk menghapus utang pajak yang berdasarkan ketentuan yang berlaku sebagai pelanggaran terhadap perundang-undangan perpajakan. Informan memberikan pandangan tetang faktor yang mendorong tindakan mengurangi beban pajaknya. Terdapat Informan yang memberikan jawaban lebih dari 1 (satu) faktor. faktor-faktor yang mendorong tindakan tax evasion dalam bentuk menghapuskan beban pajak menurut informan dalam penelitian ini adalah, 3 (tiga) informan berpandangan faktor beban mendorong tindakan tersebut, 1 (satu) informan berpendapat sistem perpajakan yang rumit, 3 (tiga) informan berpandangan faktor ekonomi yang mendorong tindakan tersebut, 3 (tiga) informan berpandangan faktor kepentingan diri sendiri yang mendorong tindakan tersebut, dan 2 (dua) informan berpandangan faktor birokrasi pemerintah yang mendorong tindakan tersebut. Pajak adalah hal yang wajib bagi seluruh masyarakat yang mampu dan berpenghasilan diatas rata-rata, namun saat ini masih banyak masyarakat yang pada dasarnya mampu untuk penghindaran pajak yang cukup tinggi (Binarni, 2016). Tarif pajak bukan satu-satunya faktor yang mendorong keputusan masyarakat untuk membayarkan pajak karena pada dasarnya sistem pajak secara menyeluruh juga memiliki dampak yang besar. Jika, tingkat pajak atas penghasilan dari perusahaan seseorang rendah, tetapi individu mendapati tarif pajak yang tinggi atas penghasilan pribadi, wajib pajak akan menganggap beban pajak pribadi sebagai sesuatu yang tidak adil dan memilih untuk menghapus sebagian penghasilan pribadi. (Kurniawati dan Toly, 2014). Bentuk tax evasion yang lebih parah adalah apabila wajib pajak (WP) sama sekali tidak melaporkan penghasilannya (non-reporting of income). Seperti yang dilakukan oleh salahsatu Informan dalam penelitian ini, Bapak Maxi. Dengan hadirnya Peraturan Pemerintah No. 23 Tahun 2018 menjadi ajang perluasan subjek pajak termasuk usaha-usaha dengan penghasilan kecil sekalipun. Akan tetapi, birokrasi pemerintah membuat Bapak Maxi enggan untuk ikut andil dalam pembangunan karena merasa akan sia-sia jika pajak yang dibayarkan jatuh ke tangan yang salah. Memang masih banyak masyarakat yang menganggap kalau pemerintah itu adalah pencuri uang masyarakat. Mereka juga beranggapan bahwa penggelapan pajak itu dilihat dari kondisi Indonesia saat ini yaitu banyaknya aparat pajak melakukan korupsi dari hasil uang pajak, sehingga membuat WP tidak mau membayar pajak. Memang kenyataan tersebut sering mengecewakan masyarakat. Sering kali ditemukan ketidakjujuran dari pemerintah itu sendiri dengan rentetan sejarah penggelapan pajak di Indonesia. Dalam melaporkan pajaknya, wajib pajak diminta untuk melaporkan pendapatannya secara lengkap tanpa ada satupun hal yang dihapuskan secara ilegal. Hal tersebut telah tertuang dalam Ketentuan Umum Perpajakan Tindak Pidana Pajak pasal 39 ayat (1) perbuatan sengaja bagian d. Menyampaikan SPT yang isinya tidak benar/tidak lengkap. Dalam menghapuskan beban pajak secara ilegal wajib pajak akan seluruh pendapatan agar pada saat pengisian SPT hasilnya akan nihil. Hal ini menjadi celah karena dengan terbitnya Peraturan Menteri Keuangan (PMK) No. 9/PMK.03/2018 yang mengubah ketentuan dalam PMK No. 243/PMK.03/204 tentang Surat Pemberitahuan (SPT). Salah satu perubahannya adalah ketentuan pelaporan SPT Masa Nihil. Pada Pasal 10 dalam PMK No. 9/PMK.03/2018, menyebutkan bahwa Wajib Pajak dibebaskan dari kewajiban pelaporan SPT Masa Nihil, kecuali karena adanya Surat Keterangan Domisili, SPT Masa PPh Pasal 21 atau 26 nihilnya masa Desember, dan adanya potongan $\mathrm{PPh}$ Pasal 21/26 final. Wajib pajak yang menghapuskan beban pajaknya selalu akan memberikan alasan padahal secara terang-terang menghapuskan beban pajak dan melanggar peraturan yang ada. Seperti Informan Bapak Maxi yang menghapuskan beban pajak dan tidak membayar karena birokrasi pemerintah yang kurang baik seperti korupsi dan pembangunan yang kurang merata. Sikap wajib pajak yang melakukan tindakan ini didasari keadaan disekitar. Jika berbicara lingkungan tempat tinggal wajib pajak pembangunannya kurang merata akan menimbulkan rasa tidak percaya percaya 
kepada pemerintah. Hal itu telah dijelaskan oleh Purwanto dalam Rina (2013: 16) dalam ciri ciri sikap. "Sikap tidak berdiri sendiri, tetapi senantiasa mempunyai hubungan tertentu terhadap suatu objek dengan kata lain sikap itu terbentuk dan dipelajari atau berubah senantiasa berkenaan dengan suatu objek tertentu yang dapat dirumuskan dengan jelas."

Faktor Yang Mendorong Tindakan Manipulasi Ilegal Beban Pajak. Tindakan tax evasion dalam bentuk manipulasi beban pajak ditanggapi beragam oleh informan. ketika ditanyai mengenai faktor yang mendorong tindakan tax evasion dalam bentuk manipulasi ilegal beban pajak, 2 (dua) informan mengatakan tindakan itu muncul karena faktor beban pajak yang dirasa terlalu tinggi, 1 (satu) informan berpendapat sistem perpajakan yang rumit, 1 (satu) informan berpendapatan tindakan itu muncul karena faktor kepatuhan, 1 (satu) informan berpendapatan adanya faktor kepentingan diri sendiri terhadap tindakan tersebut. 1 (satu) informan mengatakan adannya faktor ekonomi yang melatarbelakangi, dan 2 (dua) informan berpendapat faktor birokrasi pemerintah yang mendasari tidakan tersebut. Salah satu Informan memberikan pendapat bahwa semakin tinggi intelegensi masyarakat terhadap pajak, akan lebih membatasi masyarakat dalam mengikuti kewajiban perpajakan. Hal unik lainnya katakan oleh Bapak Roni lewat wawancara langsung, beliau berkata bahwa ada bentuk manipulasi yang ia lakukan dalam usahanya. Namun bukti palsu yang ia buat untuk menutupi selisih pendapatan dan nota yang ada. Bapak Roni mencurigai adanya tindak kecurangan yang dilakukan karyawannya. Tentu saja hal itu akan berdampak pada pendapatan usaha dari Bapak Roni. Apabila kita meninjau Pasal 39A Ayat (1) UU KUP Tindak Pidana Pajak. Orang yang memiliki kesengajaan: Menerbitkan dan/atau menggunakan faktur pajak, bukti pemungutan pajak, bukti pemotongan pajak, dan/atau bukti setoran pajak yang tidak berdasarkan transaksi yang sebenarnya. Faktur pajak fiktif adalah faktur pajak yang diterbitkan tidak sesuai dengan transaksi yang sesungguhnya atau diterbitkan oleh pengusaha yang belum dikukuhkan menjadi Pengusaha Kena Pajak (Yamin \& Putranti, 2009:20). Pembuatan faktur fiktif erat dengan kaitannya dengan Pajak Pertambahan Nilai. Faktor-faktor yang mendorong Wajib Pajak dalam melakukan penerbitan faktur pajak fiktif adalah untuk memperoleh keuntungan pribadi berupa pengembalian Pajak Pertambahan Nilai (restitusi) (Khairani dan Mukharromah, 2015:12). Manipulasi ilegal sebenarnya tidak perlu apabila hal yang menjadi faktor yaitu tingginya beban pajak. Karena sudah menjadi jelas beban pajak yang hanya $0.5 \%$ dari peredaran bruto bukanlah angka yang besar. Akan tetapi pandangan masyarakat tidak boleh di abaikan dan harus menjadi fokus penting pemerintah. Mengingat biaya hidup masyarakat selalu dinamis bahkan konstan peningkatannya, hal itu akan mendorong seseorang untuk mengambil jalan-jalan pintas yang melanggar peraturan yang ada. Meski begitu, manipulasi ilegal yang berujung pada tindakan yang melangar undang-undang merupakan tindakan tidak baik meski apapun alasan yang mendasarinya.

\section{KESIMPULAN DAN SARAN}

\subsection{Kesimpulan}

Berdasarkan hasil dan uraian, penulis menarik kesimpulan mengenai ananlisis faktorfaktor yang mendorong tindakan tax evasion pada wajib pajak UMKM di Kecamatan Madidir Kota Bitung :

1. Faktor - faktor yang mendorong wajib pajak UMKM untuk melakukan tindakan tax evasion dalam bentuk mengurangi beban pajak adalah faktor beban pajak yang dirasa terlalu tinggi, ekonomi, ketidaktegasan pemerintah, kepatuhan dan ketidakpercayaan kepada birokrasi pemerintah.

2. Faktor - faktor yang mendorong wajib pajak UMKM untuk melakukan tindakan tax evasion dalam bentuk menghapuskan beban pajak adalah faktor beban pajak yang terlalu tinggi, ekonomi, kepatuhan, dan ketidakpercayaan kepada birokrasi pemerintah. 
3. Faktor - faktor yang mendorong wajib pajak UMKM untuk melakukan tindakan tax evasion dalam bentuk manipulasi ilegal beban pajak adalah faktor beban pajak yang dirasa terlalu tinggi, ekonomi, kepatuhan, dan ketidakpercayaan kepada birokrasi pemerintah.

\subsection{Saran}

Peneliti menyampaikan saran dari hasil penelitian sebagai berikut :

1. Dalam usaha menekan angka tindakan tax evasion di Kecamatan Madidir Kota Bitung serta dalam upaya meningkatkan penerimaan pajak daerah maupun pusat, masyarakat mestinya membantu dalam bentuk menghindari dan menghilangkan kebiasaan tax evasion. masyarakat harus lebih terbuka kepada pemerintah dan menaati segala aturan yang ada. Mulai dari usaha mencari tahu informasi perpajakan, melaporkan penghasilannya sesuai dengan yang seharusnya, hingga menjadi pelopor dalam membayar pajak di lingkungan sekitar.

2. Bagi aparatur pajak, diharapkan untuk tidak lelah memberi informasi kepada masyarakat serta menindak para pelaku tindak tax evasion di Kecamatan Madidir Kota Bitung. Melakukan pendekatan kepada masyarakat adalah hal yang penting. Sosialisasi dan penyuluhan tentang pentingnya pajak harus tetap disuarakan agar masyarakat sadar dan mau bekerja sama dalam pembangunan.

\section{DAFTAR PUSTAKA}

Agoes, Sukrisno dan Estralita Trisnawati. 2010. Akuntansi Perpajakan. Edisi 2 Revisi. Salemba empat. Jakarta

Birnani, Indah. 2016. Motif-motif Penggelapan Dana Pajak Di Kota Makassar Dalam Tinjauan Ekonomi Islam). Skripsi. Fakultas Ekonomi dan Bisnis Islam. UIN Alauddin Makassar. Makassar.

Halim A., dan Kusufi S. 2014. Teori, Konsep dan Aplikasi Akuntansi Sektor Publik.. Salemba Empat. Jakarta.

Khairani, Dienda dan Awwaliatul Mukharromah. 2015. Lebih Mudah, Aman dan Nyaman dengan E-Faktur, Inside Tax Ed.33. Jakarta

Kurniawati, Meiliana dan Agus Arianto Toly. Analisis Keadilan Pajak, Biaya Kepatuhan, dan Tarif Pajak terhadap Persepsi Wajib Pajak Mengenai Penggelapan Pajak Di Surabaya Barat. Tax \& Accounting Review, Vol 4, No 2, 2014. Program Akuntansi Pajak Program Studi Akuntansi Universitas Kristen Petra. Surabaya.

Mardiasmo, 2018. Perpajakan Edisi Terbaru. Andi. Yogyakarta.

Moleong, 20011. Metode Penelitian Kualitatif. PT. Rosdakarya. Bandung.

Peraturan Menteri Keuangan Nomor 182/PMK.03/2015 Tahun 2015 Tentang Tata Cara Pendaftaran Nomor Pokok Wajib Pajak, Pengukuhan Pengusaha Kena Pajak, Penghapusan Nomor Pokok Wajib Pajak, Dan Pencabutan Pengukuhan Pengusaha Kena Pajak. Berita Negara Republik Indonesia Tahun 2015 Nomor 1466. Jakarta

Pratiwi, Rina, Purwanto. 2013.Pengaruh Pemahaman Materi Hak Asasi Manusia Terhadap Sikap Kemanusiaan Siswa Kelas VII Di Smp Negeri 2 Hulu Sungka Kabupaten Lampung Utara Tahun Pelajaran 2012/2013. Jurnal Kultur Demokrasi. Universitas Lampung. Bandar Lampung Universitas Lampung

Prihadi, Dedi. 2009. Penghindaran Atau Penggelapan Pajak?. Artikel. Tegal

Rahayu, Siti Kurnia. 2010. Perpajakan Indonesia Konsep dan Aspek Formal. Graha Ilmu. Yogyakarta.

Sekaran, Uma. 2011. Research Methods for business Edisi I and 2. Salemba Empat. Jakarta. Suandy, Erly. 2011. Perencanaan Pajak. Salemba Empat. Jakarta.

Undang - Undang Republik Indonesia Nomor 16 Tahun 2009 Tentang Penetapan Peraturan Pemerintah Pengganti Undang - Undang Nomor 5 Tahun 2008 Tentang Perubahan 
Keempat Atas Undang - Undang Nomor 6 Tahun 1983 Tentang Ketentuan Umum dan Tata Cara Perpajakan Menjadi Undang - Undang. 31 Desember 2008. Lembaran Negara Republik Indonesia Tahun 2008 Nomor 211. Jakarta.

Undang - Undang Republik Indonesia Nomor 36 Tahun 2008 Tentang Perubahan Keempat Atas Undang-Undang Nomor 7 Tahun 1983 Tentang Pajak Penghasilan. Lembaran Negara Republik Indonesia Tahun 2008 Nomor 133. Jakarta

Yamin, Luiyanto, Putranti, Titi Muswati. 2009. Model penyelewengan Pajak Menggunakan Faktur Pajak Fiktrif. Jurnal Ilmu Administrasi dan Organisasi, Vol. 16 No. 1. Hal. 17. Universitas Indonesia. Jakarta.

Zain, 2008. Manajemen Perpajakan. Edisi ke-3. Salemba Empat. Jakarta 